\title{
KRITERIA ISTITHA'AH DALAM BERHAJI MENURUT HUKUM FIQH KONTEMPORER
}

\author{
Said Rizal, Yusriando \\ Universitas Prima Indonesia \\ Jalan Skip, Simpang Sikmabing, Medan, Sumatera Utara \\ Email : saidrizal@ unprimdn.ac.id
}

\begin{abstract}
Abstrak
Hajj is a Worship by going to Baitullah in Mecca and Medina to carry out ritual worship according to the procedures governed by Islamic law. The command to perform the pilgrimage has been stated in the Qur'an and the Hadith. The order is addressed to Muslims who have met the criteria of istitha'ah (able), both in terms of physical-spiritual and cost. In this sophisticated era, the desire of the people in carrying out the pilgrimage is very high. Istitha'h is the ability to perform Hajj in terms of physical health and supplies sufficient to depart and return, as well as supportive security during the Hajj journey and implementation. This discussion aims to determine the boundaries of istitha'a in the Hajj according to contemporary fiqh. To obtain data in this discussion, a literature study was carried out, namely by studying the Al-Quran, Al-Hadith and fiqh books relating to the chapter of the pilgrimage and other books that are related to the problems in this study. From the results of the discussion it can be seen that, someone who has a healthy body, able to hajj.
\end{abstract}

Keywords: Hajj, worship, baitullah, istitha'ah, able

\section{Intisari}

Haji adalah Ibadah dengan pergi ke Baitullah di Mekkah dan Madinah untuk melaksanakan ritual peribadatan sesuai dengan tata cara yang diatur oleh syariat Islam. Perintah melaksanakan ibadah haji telah tertuang di dalam Al-Qur'an dan Hadis. Perintah tersebut ditujukan kepada orang-orang Islam yang telah memenuhi kriteria istitha'ah (mampu), baik dari segi jasmani-rohani maupun biaya. Era yang serba canggih ini, keinginan masyarakat dalam melaksanakan ibadah haji sangatlah tinggi. Istitha'h adalah kemampuan untuk melaksanakan haji yang dilihat dari segi kesehatan fisik dan perbekalan yang cukup untuk berangkat dan kembalinya, serta keamanan yang mendukung selama perjalanan dan pelaksanaan ibadah haji. Pembahasan ini bertujuan untuk mengetahui batasan istitha'a dalam berhaji menurut fiqh kontemporer. Untuk memperoleh data dalam pembahasan ini, maka dilakukan kajian kepustakaan, yaitu dengan mempelajari Al-Quran, Al-Hadis dan kitab-kitab fiqh yang berkaitan dengan bab haji serta buku-buku lain yang ada kaitannya dengan 
permasalahan dalam penelitian ini. Dari hasil pembahasan dapat diketahui bahwa, seseorang yang mempunyai sehat badan, sanggup berhaji.

Kata kunci : Haji, ibadah, baitullah, istitha'ah, mampu 


\section{A. Latar Belakang Masalah}

Haji adalah Ibadah dengan pergi ke Baitullah di Mekkah dan Madinah untuk melaksanakan ritual peribadatan sesuai dengan tata cara yang diatur oleh syariat Islam. Perintah melaksanakan ibadah haji telah tertuang di dalam Al-Qur'an dan Hadis. Perintah tersebut ditujukan kepada orang-orang Islam yang telah memenuhi kriteria istitha'ah (mampu), baik dari segi jasmani-rohani maupun biaya.

Era yang serba canggih ini, keinginan masyarakat dalam melaksanakan ibadah haji sangatlah tinggi. Hal ini dapat ditelusuri dari data kuota jamaah haji tahun 2016 sesuai Keputusan Menteri Agama No. 210 Tahun 2016 Tentang Penetapan Kuota Haji Tahun 1437 H/ 2016 M sebagai berikut: 1 Kuota Jama'ah Haji Tahun 2016 No. Kelompok/Golongan Jumlah 1. Haji Reguler 155.200 orang 2. Haji Khusus 13.600 orang Total Jamaah 168.800 orang Data tersebut adalah data kuota jamaah yang akan berangkat ke tanah suci pada tahun $2016^{1}$.

kita telusuri juga data haji yang berangkat di tahun 2017 sangat drastis kenaikan dibandaingkan dengan Tahun 2016. Jika kita melihat total keseluruhan data yang berangkat Haji pada tahun 2017 berjumlah sebanyak 221.000 orang, maka sesuai dengan

\footnotetext{
${ }^{1}$ Keputusan Menteri Agama No. 210 Tahun 2016 Tentang Penetapan Kuota Haji Tahun 1437 H/ 2016 M, ditetapkan di Jakarta, 10 Mei 2016
}

data maka kenaikan sebnayak 52.200 jamaah haji yang bertambah.

Sementara itu, para jamaah haji yang masih masuk dalam daftar tunggu pemberangkatan diperkirakan jumlahnya mencapai ratusan ribu orang. Angka tersebut menunjukkan betapa tingginya keinginan masyarakat Indonesia untuk beribadah ke Baitullah. Hal ini juga mencerminkan semangat positif masyarakat muslim Indonesia untuk menyempurnakan ibadahnya, maka dengan melaksanakan rukun Islam yang kelima. Ibadah haji memerlukan persiapan lebih oleh karena itu kriteria istitha'ah (mampu) ini merupakan syarat untuk bisa melangkah menunaikan ibadah haji. Mampu dalam hal ini memiliki arti sebagai kemampuan (kesanggupan) seseorang untuk melaksanakan ibadah haji, baik dari segi tenaga maupun biaya. Dari segi tenaga, seseorang haruslah memiliki kekuatan diri, baik jasmani dan rohani, agar dapat melaksanakan rukun dan wajib haji dengan baik, meskipun sering dijumpai orang yang berangkat ke Baitullah dengan kondisi sakit dengan izin Allah justru dapat melaksanakan ibadah haji dengan baik, segar dan sehat.

\section{B. Rumusan Masalah}

Berdasarkan latar belakang masalah yang telah diuraikan di atas, maka yang menjadi rumusan masalah adalah; Bagaimana kriteria istitha'a dalam berhaji menurut fiqh kontemporer? 


\section{Metode Peneltian}

Pada dasarnya dalam setiap penulisan karya ilmiah, data yang lengkap serta objektif sangat diperlukan, hal ini tentunya harus sesuai dengan metode yang akan digunakan dalam penelitian ini nantinya.

1. Jenis Penelitian

Dalam pembahasan skripsi ini, penulis menggunakan metode deskriptif analisis yaitu suatu metode yang bertujuan membuat deskripsi, gambaran atau lukisan secara sistematis, faktual, dan akurat mengenai fakta-fakta, sifat-sifat serta hubungan antar fenomena yang diselidiki. Ini dilakukan setelah melaui proses analisa data-data yang diperoleh dari pembahasan. Di mana dalam penulisan ini akan menjelaskan ukuran, batasan dan kriteria istitha'a dalam berhaji menurut fiqh kontemporer.

2. Tehnik Pengumpulan Data

\section{a. Data Primer}

Data primer merupakan sumber data yang sangat penting dan diutamakan dalam suatu penelitian/pembahasan sebagai dalil yang kuat. Teknik pengumpulan data primer dilakukan kajian pustaka (library research), yaitu dengan mempelajari Al-Quran, hadist dan kitab-kitab fiqkh yang berkaitan dengan bab haji serta buku-buku lain yang ada kaitannya dengan permasalahan dalam skripsi ini.

b. Data sekunder
Data Sekunder ialah data pelengkap dalam penelitian ini penulis merujuk pada karangan ilmiah lain yang berkaitan dengan objek yang penulis kaji, yang berhubungan dengan haji. Data ini bertujuan untuk mengetahui dan mendapatkan penjelasan yang lebih jelas tentang kriteria istitha'a dalam berhaji.

3. Langkah Analisis Data

Pembahasan skripsi ini menggunakan metode deduktif dimana data yang telah berhasil dihimpun akan dianalisis secara kualitatif dengan menggunakan metode deskriptif, yaitu memaparkan data-data yang terkait dengan masalah yang dibahas yang ditemukan dalam berbagai literatur dan kesimpulannya diambil melalui logika deduktif yaitu memaparkan masalah-masalah yang bersifat umum kemudian ditarik suatu kesimpulan yang bersifat khusus. Metode ini digunakan sebagai metode analisis berdasarkan teori umum yang pasti kebenarannya, dalam penelitian kali ini tentang kriteria istitha'a dalam berhaji (kajian fiqh kontemporer).

Dalam penyusunan dan penulisan skripsi ini berpedoman kepada buku Pedoman Penulisan Karya Ilmiah Mahasiswa dan Pedoman Transliterasi Arab Latin, yang diterbitkan oleh Fakultas Syariah IAIN Ar-Raniry Darusalam Banda Aceh Tahun 2002. Sedangkan untuk penerjemahan ayat-ayat Al-Quran 
dikutip dari Al-Quran dan Terjemahannya yang diterbitkan oleh yayasan penyelenggaraan Penterjemahan Al-Quran Kementerian Agama RI tahun 1990

\section{HASIL PENELITIAN}

\section{Istitha'a Melaksanakan Haji Karena Hibah}

Kewajiban haji baru berlaku bagi seseorang yang memenuhi sejumlah persyaratan. Di antara persyaratan itu adalah istitha'a (kemampuan), kesehatan fisik, dan biaya selama dalam melaksanakan haji dan biaya untuk keluarga yang ditinggalkan. Persoalannya, apakah kemampuan itu mutlak berasal dari dirirnya ataukah boleh bersumber dari orang atau pihak lain. Bagaimana seandainya seseorang yang mendapatkan biaya haji dari pemerintah atau pihak berwenang, dengan syarat dia wajib melaksanakan sejumlah tugas selama musim haji. Dan bagaimana pula hukumnya orang yang ditanggung biaya pelaksanaan hajinya secara cuma-cuma oleh pihak lain. Apakah haji dengan biaya yang demikian telah melepaskan orang tersebut dari kewajiban melaksanakan haji.

Dikhususkan pada ibadah haji, seseorang yang melaksanakan ibadah haji harus memiliki kemampuan, baik kemampuan secara fisik maupun kemampuan secara finansial. Dalam hal ini kemampuan finansial yang mencakup bekal merupakan hal penting dalam melakukan ibadah haji. Baik selama dalam perjalanan maupun bagi anggota keluarga yang ditinggalkan.
Maka jika seseorang mempunyai harta yang lebih dari kebutuhan hidupnya sehari-hari, wajib baginya untuk menunaikan ibadah haji. Sebaliknya bagi seseorang yang tidak mempunyai harta yang cukup untuk memenuhi kebutuhan hidupnya, maka tidak di wajibkan untuk menunaikan ibadah haji. Hal tersebut berdasarkan pada firman Allah yang telah disebutkan di atas dan penjelasan hadist rasulullah Saw kepada sahabat yang menanyakan maksud dari ungkapan "as-sabil" pada surat Ali Imran di atas. Beliau menjelaskan arti dari kata tersebut adalah finansial dan transportasi. ${ }^{2}$

Kesemua madzab berpendapat bahwa, haji tidak wajib bagi orang yang tidak memenuhi kriteria istitha'a. Namun perbedaan hadist yang diriwayatkan dari Nabi Muhammad Saw, menyebabkan para ulama berbeda pendapat dalam menafsiri kata istitha' $a$. Madzhab Maliki mengatakan bahwa yang dimaksud istitha' $a$ adalah kemampuan sampai ke tanah suci Mekkah dan tempat-tempat ibadah haji secara fisik. Sedangkam Madzhab Syafi'i berpendapat, istitha' $a$ terbagi menjadi dua, yaitu istitha' $a$ bin nafsi (kemampuan dengan dirinya sendiri) dan istitha'a bi ghoiri nafsi (kemampuan dengan bantuan orang lain). Madzhab Hanafi berpendapat bahwa istitha'a adalah kemampuan atas bekal dan kendaran yang layak. ${ }^{3}$

2 Muhammad bin Abdul Azis AlMusnad, Fatwa-fatwa Haji dan Umrah, (terj. Asmuni Solihin Zamakhsyari), Bogor: Pustaka Imam Asy-Syafi'I,2003, hlm. 22

3 Abdur Rahman Al-Jaziri, Mazhab 
Dalam setiap tahun, tepatnya di bulan Dzulhijjah, tanah suci Mekkah selalu di banjiri oleh seluruh ummat Islam sedunia. Berbagai suku bangsa berduyun-duyun memenuhi panggilan Allah. Mereka melakukan napak tilas sejarah Nabi Ibrahim as. Menjadi haji yang mabrur adalah keinginan setiap manusia yang mampu melaksanakan ibadah haji. Karena menjadi haji yang mabrur tidak harus sedahsyat Nabi ibrahim, tetapi harus memulai hidup dengan mental dan moril yang lebih baik. Dengan kata lain, cita-cita tersebut harus terbelesit sejak dini, ketika akan datang ke Baitullah, dengan membawa harta benda yang halal dan bersih, dan pekerjaan yang halal pula. Seperti yang ada pada beberapa tahun yang lalu, yakni pemerintah memberikan fasilitas haji kepada para pejabat dan anggota DPR maupun DPRD, yang diistilahkan dengan Haji Abidin (haji Atas biaya Dinas). ${ }^{4}$ Yakni menanggung biaya perjalanan haji sepenuhnya bagi para pejabat. Tindakan seperti ini sangat merugikan para calon jama'ah haji, karena biaya haji bagi pejabat diambilk dari Biaya Perjalanan Ibadah Haji (BPIH).

Melaksanakan ibadah haji atas biaya dinas atau yang di sebut dengan haji abidin, merupakan suatu pemerasan bagi calon jama'ah haji. Sebagaimana dalam istitha'a telah disyaratkan bahwa bekal dalam

Arba'ah, Cet. I, Beirut: Dar Ihyaut Turats AlAraby, 2003, hlm. 633-635.

${ }^{4}$ DPRD Mataram Setuju

Penghapusan Fasilitas Haji Bagi Pejabat, http://www. Republika.co.id/koran-detail. melaksanakan ibadah haji harus halal dari sesuatu yang syubhat. Adapun jika bekal tersebut berasal dari sesuatu yang haram, maka ibadah hajinya dihukumi sah, tetapi tidak mabrur dan tidak diterima ibadah hajinya. Hal ini sesuai dengan pendapat mazhab Syafi'i, Maliki, Hanafi dan jumhur ulama. Sedangkan menurut mazhab Hambali yaitu tidak menjadi sah ibadah hajinya jika menggunakan harta yang haram. ${ }^{5}$

Namun Said Agil Husin alMunawar dalam bukunya "fikih haji" menyebutkan bahwa, dalam kasus seseorang yang mendapatkan bantuan biaya dari pemerintah untuk melaksanakan haji (haji dengan biaya dinas) atau yang lebih dikenal dengan haji abidin, dan ia diangkat sebagai petugas haji di Mekkah, seperti petugas kesehatan, pembimbing ibadah haji, dan supir, maka haji orang tersebut sah dan diterima Allah, selama ia memenuhi rukun dan syarat haji. Istitha'a dalam hal ini telah terwujud dengan menjalankan kewajibannya sebagai petugas haji dengan mendapatkan imbalan tidak membayar ongkos haji. ${ }^{6}$

Sementara dalam kasus lain, orang yang ditanggung haji biaya pelaksanaan haji oleh pihak lain, maka pemberian itu dianggap sedekah bagi dirinya dan ia berhak penuh atas harta sedekah tersebut. ${ }^{7}$

Ibadah haji merupakan ibadah

5 Muhammad bin Abdul Azis AlMusnad, Op.cit, hlm .9.

6 Said Agil Husaini al-Munawar, Abdul Halim, Op.cit, hlm. 332.

${ }^{7}$ Ibid, 
yang di fardhukan bagi setiap orang Islam baik laki-laki maupun perempuan dengan syarat-syarat tertentu. Salah satu dari syarat-syarat tersebut adalah istitha'a (mampu). Dari kesepakatan para ulama, haji tidak diwajibkan bagi orang yang tidak mampu.

Al-Aufi berkata, diriwayatkan dari Ibnu Abbas, beliau berkata orangorang terdahulu pergi ibadah haji meninggalkan keluarganya dengan tanpa membawa bekal. Dan mereka berkata, kami berhaji ke Baitullah, apakah Allah akan memberi makan kepada kita? Maka Allah berfirman bawalah bekal yang bisa menjaga kamu dari meminta-minta kepada orang lain. ${ }^{8}$

Dari keterangan di atas bahwa diwajibkan bagi seseorang yang menunaikan ibadah haji untuk membawa bekal yang dapat mencukupi kebutuhannya selama melaksanakan ibadah haji. Menurut Madzhab Syafi'i istitha'a (kemampuan) terbagi menjadi dua bagian, yaitu kemampuan seseorang karena dirinya sendiri dan kemampuan seseorang karena adanya bantuan dari orang lain.

Apabila kemampuan dalam melaksanakan ibadah haji bukan karena dirinya sendiri melainkan dengan bantuan atau pemberian dari orang lain, maka perlu adanya pemilahan bentuk-bentuk dari bantuan tersebut, yakni:

a. Seorang anak

${ }^{8}$ Ismail Bin Katsir Al Qurasyi AdDimasyqy, Tafsir Ibnu Katsir, Juz I, Singapura: Sulaiman Maz'i, 2004, hlm. 238.

$\begin{array}{lr}\text { menghibahkan } & \text { kepada } \\ \text { orang lain } & \text { untuk } \\ \text { menghajikan } & \text { orang } \\ \text { tuanya. } & \end{array}$

Jika pemberi bantuan (hibah) adalah seorang anak, dan pemberian tersebut berupa ongkos haji yang diberikan kepada orang lain untuk menghajikan orang tuanya, maka menurut pendapat iman Ghazali, AlMahamili dan Imam Ibnu Shabagh, wajib baginya melaksanakan ibadah haji. ${ }^{9} \quad$ Misalnya, seseorang tidak mampu melaksanakan ibadah haji dengan sendirinya karena sakit parah dan tidak mempunyai ongkos untuk keberangkatannya, maka ibadah haji boleh dikerjakan oleh orang lain, dengan ongkos haji yang diberikan anaknya tersebut.

$$
\begin{aligned}
& \text { b. Seorang anak } \\
& \text { menghibahkan kepada } \\
& \text { orang tuanya supaya } \\
& \text { menyewa orang lain } \\
& \text { untuk menghajikannya. } \\
& \text { Apabila pemberian hibah }
\end{aligned}
$$
berupa ongkos haji yang diberikan kepada orang tuanya yang sakit agar menyewa orang lain untuk menghajikannya (orang tua) maka hukumnya tidak wajib baginya (penerima) untuk melaksanakan ibadah haji karena pemberian tersebut. ${ }^{10}$ Sama halnya kalau orang tua tersebut dalam keadaan sehat dan anaknya memberikan harta untuk ongkos ibadah haji maka tidak wajib baginya melaksanakan ibadah haji dan

9 Yahya bin Abil Khoir Salim AlImroni, Al-Bayan Fi Madzhabi Al-Imam AsSyafi'I, Juz IV, Darul Minhaj, tt, hlm. 44-45.

${ }^{10}$ Ibid, hlm. 45. 
menerima pemberian tersebut. ${ }^{11}$ Karena seseorang tersebut bukan termasuk dalam kategori orang yang mampu (mustathi'), kecuali setelah memiliki harta benda, dan proses pemilikan harta tersebut adalah termasuk kasab, sedangkan mencari harta benda untuk bekal haji itu tidak wajib.

Adapun hal yang menyebabkan perbedaan hukum antara kedua bentuk tersebut, karena pemberian dalam bentuk pertama adalah bentuk hibah dalam bentuk jasa, sedangkan bentuk yang kedua merupakan hibah dalam bentuk benda.

c. Seseorang memberikan hibah kepada orang lain

Jika pemberi hibah adalah orang lain, dan pemberian tersebut berupa uang supaya menyewa orang lain untuk menghajikannya atau pemberian tersebut untuk dirinya sendiri, maka hukumnya tidak wajib bagi si penerima untuk melaksanakan ibadah haji. ${ }^{12}$ Namun bila bantuan itu sifatnya tidak mengikat maka dianjurkan untuk menerimanya. Misalnya, di Indonesia umumnya pemberian paket haji dalam setiap tahun bagi pegawai pemerintah yang belum pernah melaksanakn ibadah haji. Hal ini termasuk telah menggugurkan kewajiban ibadah haji meskipun biayanya tidak dari dirinya sendiri

11 Imam Abu Zakariyya Yahya Raudhat Al-Thalibin, Beirut: Dar Ibnu Hazm, 2002, hlm.36.

12 Yahya bin Abil khoir Salim AlImroni, op.cit, hlm. 45.

\section{Kriteria Istitha'a Menurut Fiqh Kontemporer}

Ibadah haji sebagai rukun Islam kelima merupakan ibadah yang berat secara ekonomis, fisik, dan spiritual. Setelah bertahun-tahun mengumpulkan uang maupun barangbarang berharga, barulah calon jamaah haji dapat benar-benar siap menunaikan rukun Islam yang ke lima itu. Menurut ilmu fikih, ibadah haji diperuntukkan bagi orang-orang yang mampu menempuh perjalanan ke tanah suci saja. Sebagian ulama menyebutkan, pengertian mampu itu artinya jika seorang Muslim mampu secara fisik pergi ke Baitullah, mampu membiayai perjalanan, dan memberikan kemampuan kepada keluarganya yang ditinggalkan.

Namun, kemajuan zaman tampaknya semakin mengubah makna mampu dengan pengertian yang lain. Apalagi hal itu didukung dengan semakin sadarnya umat Islam akan kewajiban menunaikan ibadah haji ini. Sehingga, praktis tidak hanya orang yang mampu membiayai perjalanan dirinya dan membiayai keluarga yang ditinggalkan pergi haji yang bisa menunaikan rukun Islam kelima, namun pengertian mampu yang lebih luas dari itu.

Masalah haji sudah menjadi urusan semua umat Islam di seluruh dunia, dan segala sesuatunya ditetapkan negara-negara yang tergabung dalam Organisasi Konferensi Islam (OKI). OKI telah menetapkan bahwa setiap negara hanya diperbolehkan memberangkatkan satu perlima dari jumlah penduduk. Dengan demikain 
yang penduduknya berdasarkan penghitungan sekitar 210 juta hanya boleh mengirimkan sebanyak 210.000 orang seperti jumlah jamaah haji di Indoneisa tahun ini. Tujuan setiap jamaah haji adalah mendapatkan haji yang mabrur. Mencapai kemambruran tidaklah mudah. Mulai dengan niat yang ikhlas dan hati yang pasrah serta tenang untuk memenuhi panggilan Allah Swt. Saat mengenakan pakaian ihram adalah ibarat telah siap dibungkuskan dengan kain kafan menghadap Allah Swt. ${ }^{13}$

Dalam hubungan dengan keadaan umat masa sekarang, makna kesanggupan untuk melakuakan perjalanan ke Baitullah sangat mungkin untuk diperluas maknanya sehingga antara pelaku dengan ritual haji bersinergi dengan kemabruran haji yang dilaksanakannya. Perluasan makna kesanggupan tersebut, meliputi ; fisik, finensial, kesehatan, knowleg, psikomotorik, adaptasi, implementsi, dan sosialisasi.

Seseorang dianggap sudah mempunyai kemampuan (istitha'a) dalam berhaji yaitu orang-orang yang sudah memiliki bekal (uang), baik untuk membayar Ongkos Naik Haji, $(\mathrm{ONH})$, biaya selama pelaksanaan haji, dan mempunyai alat transportasi, serta keluarga/orang-orang dibawah tanggungannya yang ditinggalkan mencukupi segala kebutuhan pokoknya, dan waktu masih

13 Laporan Akhir Komosi Pengawas Persaingan Usaha Republik Indonesia (KPPURI), Evaluasi Kebijakan Pemerintah Terkait Dengan Persaingan Usaha Dalam Rancangan Perubahan Undang-undang No.17 Tahun 1999 tentang Penyelenggaraan Haji. memungkinkan (pendaftaran calon jama'ah haji belum ditutup) walau harus menuggu daftar antrian untuk keberangkatan. Waktu yang masih memungkinkan di sini bukan hanya dimaksud waktu pendaftaran haji, akan tetapi mencakupi waktu keberangkatan atau pelaksanaan ibadah haji yang tidak terhalang oleh hal-hal lain yang harus didahulukan untuk melakukannya.

Mengenai istitha'a Al-Jusas berkata bahwa, orang sakit dan orang tua merupakan orang-orang yang mempunyai kemudharatan ('odhor) untuk sampai ke Mekkah, maka bagi orang tersebut tidak diwajibkan haji karena tidak mempunyai kemampuan dalam segi kesehatan. Walaupun mereka telah mempunyai kemampuan dalam hal lain, seperti belanja dan alat transportasi, namun kesehatan dari tiap-tiap calon jamaah haji merupakan bagian dari syarat-syarat istitha' $a{ }^{14}$

Kemudian orang yang berhaji harus mengerti cara pelaksanaan haji, yaitu ilmu yang menyangkut masalah haji dan umrah atau yang lebih dikenal dengan manasik haji dan umrah. Sebab dalam realitanya di Tanah Suci, banyak ditemukan jamaah yang karena pengetahuan masalah haji kurang, mungkin karena kurangnya mengikuti manasik, tidak mengetahui harus bagaimana dan dalam posisi apa seharusnya yang dilakukan dalam rangkaian ritual ibadah hajinya itu. Kemudian orang yang berhaji itu sehat jasmani dan rohani, dalam arti bukan

14 Muhammad Ali As-Sabuni, Tafsir Ayat Ahkam, Cairo: Dar as-Sabuni, 2007, hlm.294 
orang yang sudah terlalu tua dan idiot. Namun dalam masalah ini, para ulama ada yang mengatakan wajib haji bagi orang yang bodoh/idiot. Akan tetapi bagi dia itu tidak diberikan bekal (uang), namun harus didampingi oleh keluarganya, dan segala keperluannya selama pelaksanaan ibadah haji diatur oleh orang yang mendampinginya. ${ }^{15}$

Untuk masa sekarang, pengetahuan tentang tatacara pelaksanaan haji tidak lagi menjadi suatu persoalan, karena sebelum keberangkatan haji tiba, para jamaah sudah dibekali dengan berbagai pengetahuan, baik yang berkaitan dengan perbuatan haji maupun hal-hal lain yang berkaitan dengan kehidupan jamaah selama pelaksanaan haji berlangsung.

Selanjutnya, orang yang berhaji itu tidak mempunyai halangan untuk berhaji, seperti mempunyai tugas yang diembankan kepadanya yang tidak boleh ditunda, seperti Pegawai Negeri Sipil (PNS), atau pegawai swasta. Jika mereka tidak terbebas dari hal tersebut, maka tidak wajib haji karena belum termasuk orang yang mempunyai kemampuan (istitha'a). Termasuk dalam masalah ini adalah narapidana yang sedang menjalani masa hukuman. Selanjutnya orang yang berhaji itu bebas dari halangan atau larangan dari pemerintah yang zalim, yakni pemerintah yang melarang untuk melaksanakan ibadah haji. Orang tersebut tidak dibolehkan melaksanakan haji pada saat itu tetapi

15 Djmaluddin Dimjati, Panduan Ibadah Haji dan Umrah Lengkap, Solo: Era Intermedia, 2006, hlm. 20-21. ia wajib membiayai orang lain yang sudah menunaikan haji untuk menghajikannya jika diduga kuat ia tidak lagi memiliki kesempatan haji sendiri. ${ }^{16}$

Maka dengan demikian dapat dipahami bahwa, kemampuan (istitha'a) bukan hanya dilihat dari segi kecukupan finensial keuangan, namun ilmu pengetahuan, kesehatan, kesiapan mental, serta niat yang tulus sangat menentukan kesuksesan dalam pelaksanaan ibadah haji. Panggilan Allah Swt kepada hamba-hamban-Nya untuk beribadah haji hanya ditujukan kepada mereka yang mempunyai kesanggupan. Kesanggupan yang dimaksud yaitu orang-orang yang sanggup mendapatkan perbekalan dan alat-alat pengangkutan serta sehat jasmani dan perjalanannya aman.

\section{Analisis Penulis}

Tidak diragukan lagi bahwa haji adalah sebuah kewajiban terbesar di dalam ajaran Islam, dan ia merupakan syiar yang terbesar pula. Kefardhuan/kewajiban haji telah ditetapkan oleh Al-Qur'an, Sunnah, dan Ijma'. Di dalam Al-Qur'an, Allah telah berfirman: "Mengerjakan haji adalah kewajiban manusia terhadap Allah, yaitu (bagi) orang yang sanggup mengadakan perjalanan ke Baitullah; Barangsiapa mengingkari (kewajiban haji), maka sesungguhnya Allah Maha Kaya (tidak memerlukan sesuatu) dari semesta alam." (Ali Imran: 97). Dan Allah telah meletakkan ungkapan "wa

16 Fatwa Majelis Ulama Indonesia Nomor: 01 Tahun 2001 tentang Haji bagi Narapidana 
man kafara (dan barangsiapa yang ingkar)" pada posisi ungkapan "wa man lam yahujj (dan barang siapa yang tidak melaksanakan haji)" atau menentang pelaksanaan haji dan sengaja meninggalkannya, di dalam ayat ini Allah menggunakan kata alkufur sebagai ancaman bagi orang yang tidak melaksanakan haji dan untuk menakut-nakuti mereka.

Sedangkan hadist-hadist yang menyatakan tentang kewajiban haji banyak sekali, di antaranya adalah hadist "Islam didirikan atas lima perkara..." dan di dalam hadist itu dinyatakan, "dan melaksanakan ibadah haji ke Baitullah bagi yang mampu." (HR. Muttafaq'alaih). Rasulullah Saw menyatakan kepada para sahabatnya, "Sesungguhnya Allah telah mewajibkan kepada kalian ibadah haji, maka berhajilah", maka di antara sahabat ada yang bertanya, "Apakah setiap tahun, wahai Rasulullah?", Rasul menjawab, "Kalaulah seandainya kujawab "Ya", maka ibadah haji diwajibkan kepada kalian setiap tahun dan kalian pasti tidak dapat memenuhinya".

Merupakan rahmat Allah menjadikan kewajiban haji bagi kita sekali seumur hidup. Oleh karena itu, ulama salaf menyebut shalat lima waktu dengan timbangan harian, dan shalat jum'at dengan timbangan mingguan, zakat fitrah dan puasa ramadhan dengan timbangan tahunan, dan haji dengan timbangan seumur hidup. Allah telah mewajibkan haji dengan Al-Qur'an, Sunnah, dan Ijma', dan telah sepakat seluruh umat Islam dengan wajibnya haji bagi orang yang mampu melaksanakannya walaupun mereka berbeda mazhab dan aliran.

Mengapa dikatakan di dalam haji "man istatha'a ilaih sabila (bagi yang mampu menempuhnya)?" karena haji merupakan ibadah jasmani dan harta, dan para ulama membagi-bagi ibadah kepada ibadah jasmani (jasad), dengan kata lain bahwa manusia melaksanakannya dengan anggota tubuhnya seperti shalat. Banyak manusia yang malas dan tidur, sehingga di waktu pagi dinyatakan bahwa shalat lebih baik daripada tidur, maka bangunlah muslim itu dan pergi untuk melaksanakannya, dan ia berwudhu' dengan air yang dingin. Ini merupakan ibadah jasmani dan anggota tubuh, maka shalat adalah perkataan dan perbuatan yang dimulai dengan takbir dan diakhiri dengan salam.

Begitu juga dengan puasa, ia merupakan ibadah jasmani, akan tetapi ia merupakan ibadah dengan meninggalkan sesuatu. Jadi, shalat adalah melakukan sedangkan puasa adalah meninggalkan, yaitu menahan diri dari syahwat perut dan kemaluan. Dengan kata lain, meninggalkan makan dan minum, serta menyetubuhi wanita. Jadi shalat dan puasa keduanya adalah ibadah jasmani. Zakat adalah ibadah harta yang wajib dikeluarkan karena ia merupakan sesuatu yang paling disukai jiwa manusia.

Sedangkan haji adalah ibadah jasmani dan harta, seorang muslim meninggalkan tanah airnya, melakukan perjalanan dan menghadapi segala kesulitan. Hidupnya laksana seorang anggota pramuka, tidur di kemah, tidur di tanah, dan dia merasakan berbagai 
kesulitan, dan dari sisi yang lain, ia juga mengeluarkan harta karena ia harus berpindah (melakukan perjalanan) dari negerinya ke wilayah Al Haram di tanah suci, karena ritual (syiar) haji dilaksanakan disana, karena itu ia sangat memerlukan harta (biaya) yang banyak, karena itu Allah berfirman: "Bagi yang mampu melakukan perjalanan haji”. ( Ali Imran: 97 ).

Telah dinyatakan dalam beberapa hadist ketika menafsirkan kata "kemampuan melakukan perjalanan haji" bahwa yang dimaksud dengan itu adalah adanya bekal (harta) dan kendaraan. Dengan kata lain, bahwa seseorang yang ingin melaksanakan haji harus menyiapkan bekal (harta) yang dapat mencukupi segala keperluannya untuk melakukan perjalanan dan bermukim (tinggal) serta memiliki kendaraan yang dapat membawanya dan dikendarainya. Ini menunjukkan bahwa Allah tidak membebani manusia untuk melaksanakan haji dengan berjalan kaki, namun ia mewajibkannya dengan menaiki kendaraan, dan mengendarai kendaraan jelas memerlukan harta. Kalaulah kita ingin menafsirkan makna bekal dan kendaraan dengan bahasa modern, maka kita katakan nafkah (biaya) perjalanan dan bermukim, artinya seorang muslim harus memiliki nafkah untuk melakukan perjalanannya sesuai dengan keadaannya. Di antara muslim ada yang hanya berangkat haji dengan mengendarai bus, ada yang mengendarai mobil, sedangkan yang lain mungkin saja berkata, "kami tidak bisa melakukan perjalanan kecuali dengan menaiki pesawat terbang", sedangkan yang lain merasa cukup dengan mengendarai kapal laut, maka semua manusia melaksanakan haji sesuai dengan keadaan dan kemampuannya, dan ini yang berhubungan dengan nafkah perjalanan.

Selain itu, ada juga nafkah (biaya) bermukim, yaitu segala biaya yang diperlukan seorang muslim untuk tinggal di hotel atau rumah yang disewanya, dan masuk di dalamnya seluruh biaya yang diperlukan muslim selama melaksanakan haji. Namun selain nafkah untuk melakukan perjalanan dan tinggal di Tanah Suci, ada nafkah lain yang tidak bisa dilupakan orang yang ingin melaksanakan haji yaitu memberi nafkah yang mencukupi segala keperluan keluarganya sampai akhirnya ia kembali ke kampung halamannya. Maka janganlah ia meninggalkan keluarganya tanpa nafkah dan biaya hidup, jelas tindakan itu tidak dibenarkan, inilah yang dimaksud dengan arti mampu (istitha'a).

Dalam ibadah shalat dan puasa tidak diminta syarat ini, syarat di atas hanya diminta dalam melakukan haji, karena ibadah haji adalah hijrah kepada Allah dan pergi menuju-Nya, dan itu memerlukan nafkah yang besar. Oleh karena itu, Allah menyatakan: "Bagi yang mampu melakukan perjalanan haji." 


\section{KESIMPULAN}

Bagi orang yang ingin melaksanakan ibadah haji, selama waktu pelaksaannya harus terbebas dari pekerjaan/tugas yang diembankan kepadanya, yang tugas tersebut tidak boleh ditunda atau digantikan oleh orang untuk mengerjakannya, seperti pegawai negeri/swasta atau narapidana yang sedang menjalankan masa hukuman.

Istitha'a (kemampuan) dalam berhaji bukan hanya menyangkut kecukupan finansial keunangan namun ilmu pengetahuan, kesehatan, kesiapan mental sangat diutamakan dalam pelaksanaan ibadah haji, dan ini merupakan kandungan makna dari kata istitha' $a$ yang diungkapkan oleh ulama kontemporer.

Kemampuan menunaikan ibadah haji terbagi menjadi dua, yaitu kemampuan karena dirinya sendiri dan kemampuan bukan karena dirinya sendiri. Adapun kemampuan yang bersumber dari orang lain (hibah) ulama berpendapat, bahwa orang tersebut sudah termasuk mempunyai kemampuan untuk berhaji. 


\section{DAFTAR PUSTAKA}

Abdul 'Azim bin Badawi alKhalafi, al-Wajiz, (terj. Ma'ruf Abdul Jalil), Jakarta: Pustaka as-Sunnah, 2006

Abdul Halim Hasan, Tafsir alAhkam, cet.I, Jakarta: Kencana, 2006

Abuddin Nata, Masail alFiqhiyah, Bogor: kencana, 2003

Abdur Rahman Al-Jaziri, Mazhab Arba'ah, Cet. I, Beirut: Dar Ihyaut Turats Al-Araby, 2003

Abu Malik Kamal bin Sayyid Salim, Fiqhus Sunnah lin Nissa', Jilid. I, Jakarta: Al-I'tishom Cahaya Umat, 2007

Ahmad Warson Munawwir, Kamus al-Munawir, Surabaya: Pustaka Progressif, 2002

Rahman Ritonga, Zainuddin, Fiqh Ibadah, Jakarta Selatan: Gaya Media Pratama, 1997

Departemen Agama RI, AlQur'an dan terjemah, Dirjen Bimas Islam Depag, 1998

Djmaluddin Dimjati, Panduan Ibadah Haji dan Umrah Lengkap, Solo: Era Intermedia, 2006

Fatwa Majelis Ulama Indonesia Nomor: 01 Tahun 2001 tentang Haji bagi Narapidana

Ibnu Rusyd, Bidayatul Mujtahid, (terj. Beni Sarbeni, dkk), Jakarta: Pustaka Azzam, 2006

Imam Abu Zakariyya Yahya, Syarah An-Nawawi, (terj. A.Shalahuddin, dkk), Jakarta: Pustaka Azzam, 2007

Imam Abu Zakariyya Yahya, Raudhatul Thalibin, (terj. A.Shalahuddin, dkk), Jakarta: Pustaka Azzam, 2007
Imam Jalaluddin al-Mahalli, Imam Jalaluddin as-Suyuti, tafsir jalalain, jilid 1, Bandung: Sinar Baru Algensido, 2006

Imam Muslem, Sahih alMuslim, (terj. Elly Lathifah), Jakarta: Gema Insani, 2005

Ismail Bin Katsir Al Qurasyi Ad-Dimasyqy, Tafsir Ibnu Katsir, Juz I, Singapura: Sulaiman Maz'i, 2004

Jawadi Amuli, Hikmah dan Haji, Cet. 2. Bogor: Cahaya, 2004

Muhammad Abdul Fattah al-

Banhawi, Taarikh At Tasyrii' Al Islami, 2001

Muhammad Ali As-Sabuni, Tafsir Ayat Ahkam, Cairo: Dar asSabuni, 2007

Muhammad Hasbi AshShiddieqy, Pedoman Haji, Cet.3, Semarang: PT.Pustka Rizki Putra, 1999

Muhammad bin Abdul Azis alMusnad, Fatwa-fatwa Haji dan Umrah,( terj. Asmuni Solihin Zamakhsyari), Bogor: Pustaka Imam Asy-Syafi'i, 2003

Muhammad bin 'Abdul 'Aziz al-Musnad, Fatwa-fatwa Haji dan Umrah, Bogor: Pustaka Imam asSyafi'i, 2003

Muhammad Hasbi ashShiddieqy, Tafsir an-Nuur, Jilid I, Semarang: PT. Pustaka Rizki, 2001

Muhammad Ali AshShiddieqy, Pedoman Haji, Semarang: Pustaka Rizki Putra,1999

Muhammad Ismail al-Amiru alYamaniy ash-shan'ani, Subulu asSalam Syarhi Bulughul Maram, Cairo: Dar al-Hadis, 2005 
Muhammad Jawad Mughniyah, Al-Fiqhu 'ala Al-Madzahib AlArba'ah, Beirut: Dar al-Jawad, 2002

M. Quraish Shihab, Tafsir alMisbah, jilid II, Jakarta: Lentera Hati, 2002

Mahyuddin Syaf, Fiqih Sunnah, Jilid. 5-8, Kuala Lumpur: Victory Agencie, 2001

Mas'udi, Masdar F, Islam dan Hak-hak Reproduksi Perempuan, Bandung: Mizan, 1997

M. Quraish Shihab, Tafsir alMisbah, Tanggerang: Lentera Hati, 2007

Rasyid Sulaiman, al-Fiqh alIslam, Bandung: PT.Sinar Baru Algensindo, 1994

Saleh al-Fauzan, Fiqih Seharihari, Cet. 1. Jakarta: Gema Insani Press, 2005, hlm. 307

Said Agil Husaini al-Munawar, Abdul Halim, Fikih Haji Menuntut Jama'ah Mencapai Haji Mabrur, Jakarta: Ciputat Press, 2003

Shalih bin Fauzan bin Abdullah Ali Fauzan, ringkasan Fiqh Syaikh Fauzan, (terj. Kamaluddin Sahar), Jakarta: Pustaka Azzam, 2006

Sayyid Sabiq, Fiqh Sunnah, jilid III, terj, (Abdurrahim, Masrukhin),Jakarta: Cakrawala Publishing, 2008

Umar, Nasaruddin, Argumen Kesetaran Gender Perspektif AlQur'an, Jakarta: Paramadina, 1999

Wahbah al-Zuhaili, Fiqh Islam Waadilatuh, (terj. Ahmad Sayed Hussain, dkk), Malaysia: Yayasan Pembangunan Ekonomi Islam Malaysia, 2002 http://www.

Republika.co.id/koran-detail
Yahya bin Abil Khoir Salim Al-Imroni, Al-Bayan Fi Madzhabi AlImam As-Syafi'I, Juz IV, Darul Minhaj

Yusuf al-Qaradhawi, Fatwafatwa Kontemporer, terj (Samson rahman, Dkk), Jakarta: pustaka alKautsar, 2002 